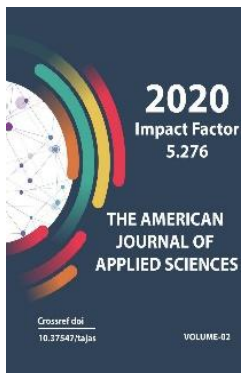

Copyright: Original content from this work may be used under the terms of the creative commons attributes 4.0 licence.

\section{Increasing The Effective Use Of Human Capital In The Digital Economy}

\section{Guzal Abdukhakimovna Alimova}

Phd In Economics, Associate Professor, Chief Researcher At The Institute For Forecasting And Macroeconomic Research Under The Ministry Of Economic Development And Poverty Reduction, Uzbekistan

\title{
ABSTRACT
}

A person and his abilities, knowledge, skills have become a key factor in the prosperity of any society and the economic development of the state. Therefore, this article is devoted to the study of the essence of "human capital", which is an important factor in the development of society in the digital economy, and ways to improve the mechanism for its effective use.

\section{KEYWORDS}

Human capital, digital economy, economic growth, investment, GDP.

\section{INTRODUCTION}

Today the countries of the world, all of humanity are going through hard times. According to the International Monetary Fund, today the world economy is practically at a standstill, the situation is worse than during the global crisis of 2008-2009, and more and more developing countries are suffering from the consequences of the coronavirus. According to Kristalina
Georgieva, head of the International Monetary Fund, "never before in

the IMF's 75-year history have so many countries needed emergency financial assistance - she told us that 85 countries have applied at one time or another." This situation requires improving the mechanism for more effective use of human capital in all areas. 
The development of human capital is important for the sustainability of people, the economy, society and the whole world. This is also important for future generations.

When countries fail to invest effectively in human capital, the costs are enormous, especially for the poor. These costs will put future generations at a disadvantage.

\section{THE MAIN FINDINGS AND RESULTS}

The experience of developed countries shows that the World Bank experts conducted research in 192 countries and came to the following conclusions:

- More than $64.0 \%$ of total economic growth is associated with human capital;

- The country's natural resources provide only about $20.0 \%$ of total economic growth;

- In countries with economies in transition, the country's production potential provides only $16.0 \%$ of total economic growth [4]. Therefore, human capital plays the main role in the economic and social development of society.

According to World Bank President Jim Yong Kim, "As the government strives to ensure economic growth, it will focus on investing in physical capital - building great bridges, new roads, modern airports and other infrastructure.

They tend to be less interested in investing in human capital, which includes public health, knowledge and skills, experience and lifestyle. This is a big mistake, because neglect of investing in human capital can drastically reduce a country's competitiveness. After all, education of talented people is necessary for the country's economic development "[4].

Indeed, to this day, a person and his abilities, knowledge, skills have become a key factor in the well-being of any society and the economic development of the state. Thus, this article is the final one in the context of the formation of the digital economy.

According to World Bank President Jim Yong Kim, "As the government seeks to ensure economic growth, it will focus on investing in physical capital - building great bridges, new roads, modern airports and other infrastructure.

As a rule, they are less interested in investing in human capital, which includes health, knowledge and skills, experience and lifestyle of the population. This is a big mistake, because neglect of investing in human capital can drastically reduce a country's competitiveness. After all, education of talented people is necessary for the country's economic development "[4].

Indeed, to this day, a person and his abilities, knowledge, skills have become a key factor in the prosperity of any society and the economic development of the state. Therefore, this article is devoted to the study of the essence of "human capital", which is an important factor in the development of society in the digital economy, and ways to improve the mechanism for its effective use.

Human capital is the sum of knowledge, skills and abilities that serve to meet the many needs of the individual and society as a whole [2]. Its role is growing in the digital economy. Because digital technologies are created by man and are applied in life.

The value of human capital can be assessed in different ways. Traditionally, economists have calculated this with the income of more educated people.

Research has shown that each additional academic year increases human income by an average of 10 percent. The quality of education is also important. For example, replacing a low-skilled teacher in a single classroom in an elementary school in the United States with a mid-career teacher could 
allow students to earn up to $\$ 250,000$ for the rest of their lives.

But cognitive (lat. Cognition "knowledge") ability is not the only indicator of human capital. Socio-emotional skills such as courage, willpower, and honesty usually bring great economic benefits. Health is also important. After all, healthy people have high labor productivity.

For example, a 2015 study in Kenya found that providing children with anthelmintic drugs, which cost as little as 30 cents, resulted in a drop in school dropout rates and a 20 percent increase in total monthly wages when they later began independent lives.

World Bank studies have shown that an increase in the number of high-speed Internet users by only $10 \%$ will allow the economy to grow by $0.4-1.4 \%$ annually. The growth rate of the "digital economy" in the world is currently almost $20 \%$ per year [3].

In developed countries, the share of the "digital economy" in GDP has reached 7\%. They are already reaping great benefits from the digital economy. In particular, the United States spends $\$ 400$ billion a year. It exports more "digital services" than the US dollar.

Today, more than $5 \%$ of the country's GDP is accounted for by the Internet, information and telecommunications industries. By 2025, the US will receive an additional \$ 20 trillion from industry "digitization". The US dollar is expected to work. This cost-effectiveness is particularly high in consumer goods ( $\$ 10.3$ trillion), the automotive industry ( $\$ 3.8$ trillion) and logistics (\$3.9 trillion) [5].

Uzbekistan also pays great attention to the introduction of the "digital economy". At present, given the massive transfer of documents and messages to digital media, the issuance of electronic signatures, communication with the state is also transferred to electronic platforms.
In his Address to the Oliy Majlis on the most important priorities for 2019 on December 28, 2018, the President of the Republic of Uzbekistan also said about the development of the digital economy in the country:

According to experts, the main thing in the digital economy is still human capital. It is also a person who somehow supports and develops digital processes and requires a lot of highly skilled labor. Research by experts also shows that it is known that a person receives almost $90 \%$ of all information that he receives through the eyes and stores it in his memory. Therefore, in the digital economy, effective use of human capital is important.

Economists have shown that when aggregating individual investment in human capital, the difference between investment in human capital and per capita income in different countries ranges from $10 \%$ to $30 \%$ [4].

For example, in the mid-19th century, Brazil encouraged the immigration of educated Europeans to São Paulo. As a result, 100 years later, the state has a higher level of education, more jobs in industry than in agriculture, and a higher per capita income.

The concept of socio-economic development of the Republic of Uzbekistan until 2030 provides for ensuring macroeconomic stability and sustainable economic growth, increasing the competitiveness of investment sectors, investment and export potential, creating favorable conditions for the development and protection of business, reducing tension in the labor market, increasing income and poverty reduction [5].

\section{CONCLUSION}

In general, the role of highly educated, experienced and modern-minded personnel and specialists in the country is invaluable for achieving strategic goals, achieving new goals and becoming one of the developed countries. This need is not easily met by the 
underlying human capital. Therefore, the full implementation of such tasks as the disclosure of human potential and its mobilization to achieve certain goals is the basis for the development of our country.

In conclusion, it should be noted that the effective use of human capital is one of the most pressing issues in the formation of the digital economy. Investments in human capital and their efficiency are one of the important factors that directly determine the country's prestige in the world.

\section{REFERENCES}

1. Address of the President of the Republic of Uzbekistan to the Oliy Majlis of December 28, 2018 on the most important priorities for 2019. www.uza.uz

2. Abduraxmonov K.X. Human Development 2013542 b.

3. Gulyamov S.S., Ayupov R.H., Abdullaev O.M., Baltabaeva G.R. Blockchain technologies in the digital economy. - $\mathrm{T}$.: TMI, Economics and Finance, 2019.

4. Umarov I.Yu. Innovative activity of the food industry of Uzbekistan. Экономика и социум, 7(74), 2020. -C. 445-448.

5. Umarov I. Yu., Yusupova M. Features of digital innovation management in business. World science: problems and innovations collection of articles of the XX$\mathrm{XI}$ International Scientific and Practical Conference: at 4 pm 2019. 